\title{
A Study on Learned Helplessness and Life Satisfaction of Women Who Play Sports and Who Don't Play Sports
}

\author{
Mustafa Baș*, Kübra Küçük, Serkan Kabak \\ Trabzon University Faculty of Sport Sciences, Trabzon, Turkey \\ Study Area: Trabzon, Turkey \\ Coordinates: $41^{\circ} \mathrm{Oo}{ }^{\prime} 18$ ? N; $39^{\circ} 43^{\prime} 21$ ? E
}

Key words: Sport psychology, Sportive activity, Quality of life

\section{Abstract}

This study was to examine the learned helplessness and life satisfaction levels of women who attend private gyms opened with controlled normalization in the covid-19 process and who failed to participate in sports. The required data were obtained from the online application performed on the women attending private gyms operating in Trabzon with controlled normalization in July 2020 and the volunteer participants that are easily accessible in the immediate surroundings, who agree to participate in the study. "Personal Information Form", "Learned Helplessness Scale" whose validity and reliability study was used to collect data within the scope of the research. As per the findings, when the learned helplessness levels of the participants who participated in sports and those who didn't were examined, a significant difference was found in favour of women who participated in sports. Again, when the life satisfaction levels of the participants were examined, a significant difference was found in favour of those who participated in sports. A statistically negative and high relationship was found between the participants' learned helplessness and life satisfaction. Considering the learned helplessness levels of the participants, no significant difference was found according to marital status, age and educationlevels.

achievements have also differed. These changes in social life during the process have given different meanings to sports. Sports have become the activities that people do to lead a healthier life, have fun, and have a good time, spend their free time and acquire it as a profession. Sport contributes to the physical, mental and psychological development of individuals. According to Erkal, (1982) sports are activities carried out to improve the physical and mental health of people, which are the basic elements of economic, social, and cultural development, to ensure the formation of personality and the development of character traits, to facilitate adaptation to the environment by providing knowledge, skills, and abilities, to provide interpersonal, inter-communal and international solidarity, cohesion and peace, to strive, to be excited, compete and prevail in the competition according to certain rules within the competition criteria as well as increasing the fighting power of the person. Sports is a socializing, competitive, cooperative and cultural phenomenon that develops spirit and physics, that improves the abilities which an individual 
acquires while transforming his/her natural environment into a human environment, and that s/he does with or without a tool, individually or collectively, within the scope of leisure activities or professionally under certain rules (Erkal, 1982).

Developments in social and scientific fields have managed to attract more and more attention of people about the benefits and importance of sports in many areas. In the past, sports, which men showed more interest in, managed to become the center of attention for women with the developments and changes in the social structure.

Even if individuals have the power and opportunity to exhibit the effort they need to exert to achieve goals and objectives, they may think that they do not have enough power to use this opportunity or not. The situation in question is mentioned as helpless behavior in the literature (Bayat, 2002).

The concept of "Learned Helplessness" was first introduced by Seligman. According to Seligman (1975), "Learned Helplessness" is based on the statement "If an animal or an individual is confronted with another result, independent of his/her/its behavior exhibited, he/she/it learns that this result is independent of his/her/its actions".

Seligman (1975) examined the emotional state of helplessness together with the concept of learning in order to explain the emergence of the concept of helplessness, with the designed researches, and they introduced the learned helplessness theory to the literature. According to Seligman learned helplessness is expressed as a state of apathy and passivity caused by the behavior of animals and humans, thinking that they have no control over the negative situations and events they face (Bilecen, 2013).

In a different definition, it is defined as the fact that the organism doesn't or cannot make the necessary effort even in cases where it can control and remove another negative result with its behavior after learning that it cannot control the result of a negative situation with its behaviors due to past experiences (Düzgün \& Hayalioglu, 2006).

Learned helplessness, which is also used as the concept of hopelessness in the literature, means that a person defines himself/herself with his/her negative characteristics, has negative expectations about the future, and accepts his/her negative experiences as unchanging and general (Abramson et al., 1989).

The concept of life satisfaction was first defined by Neugarten et al., (1961). In order to understand the concept of life satisfaction in a clear and powerful way, it will be useful to explain the definitions of the words that make up life satisfaction and then to place these words in our mind as a whole in order for us to internalize the concept. Budak (2003) defines the concept of satisfaction as the state of the organism reaching its previous balance after the psychological (curiosity, love, success) or physiological (sexuality, thirst, hunger) needs are met in the organism.
Life satisfaction can be defined as a description of the situation obtained by comparing the life expectancy of a person and the situations s/he encounters in his/her real life. Some researchers considered the concept of life satisfaction as subjective well-being, and some researchers considered happiness (Özer \& Karabulut, 2003).

The cognitive component of subjective well-being, in other words, life satisfaction, can be divided into satisfaction in some areas of life such as love, friendship, leisure time, marriage, and work, and these divided areas are also divided into original feelings such as liking, pleasure, pleasant emotions, pride, honor, and unique feelings and emotional states such as unpleasant emotions, anger, guilt, sadness, anxiety, shame (Yetim, 2001).

\section{Materials and Methods:}

This research was carried out with a relational survey model, which examines the relationship between more than one variable. Survey models are research models that aim to describe a past or present situation as it exists. The event, individual, or object subject to research is tried to be defined in its own conditions and as it is. No effort is made to change or influence them in any way. The important thing is to observe and determine the phenomenon to be known properly. Among the survey models, relational survey models are research models that aim to determine the presence and/or degree of change between two or more variables (Karasar, 2005).

The sample of the study consists of a total of 186 volunteer participants, 102 of whom attend private gyms operating in Trabzon Province in July 2020 and 84 women who do not do sports. The data used within the scope of the study were obtained from the individuals who are in the immediate environment, easily accessible and voluntarily participating in the study, and the online application to volunteer participants. "Personal Information Form" prepared by the researcher, "Learned Helplessness Scale" developed by Quinless \& Nelson (1988), Peterson et al., (1989) and adapted to Turkish by Boysan (2006) and "Life Satisfaction Scale" developed by Diener et al., (1985) and whose validity and reliability study was conducted by Dagli \& Baysal (2016) were used in the research.

The data obtained were analyzed using the SPSS 24 package program. While the differences between the two groups were determined using the t-Test, Pearson Product Moment Correlation Coefficient was used to look at the relationships between variables. The results obtained by examining the data were evaluated at a .05 significance level.

\section{Results:}

A significant difference was found between the scores obtained from the learned helplessness scale according to the participants' status of playing sports. According to the results, the learned helplessness scores of the participants 
who do not participate in sports $(=42.01$, sd $=5.94)$ were found to be significantly higher than the participants who participate in sports $(=38.23$, $s d=5.68)$. It can be said that the participants who do not participate in sports experience much more learned helplessness than the participants who participate in sports.

Investigation of Learned Helplessness Scores of Women Who Play Sports and Don't Play Sports

\begin{tabular}{llllll}
\hline Status & $\mathrm{n}$ & $X$ & $\mathrm{sd}$ & $\mathrm{t}$ & $\mathrm{P}$ \\
\hline Playing Sports & 102 & 38.23 & 5.68 & 5.74 & .001 \\
$\begin{array}{l}\text { Not Playing Sports } \\
\quad \text { Total }\end{array}$ & $\begin{array}{l}\text { T2.01 } \\
\quad 186\end{array}$ & & 5.94 & & \\
\end{tabular}

Investigation of Life Satisfaction Scores of Women Who Play Sports and Don't Play Sports

\begin{tabular}{llllll}
\hline Status & $\mathrm{n}$ & $X$ & $\mathrm{sd}$ & $\mathrm{t}$ & $\mathrm{P}$ \\
\hline Playing Sports & 102 & 18.26 & 3.91 & -4.746 & .000 \\
$\begin{array}{c}\text { Not Playing Sports } \\
\quad \text { Total }\end{array}$ & 84 & 14.92 & 4.04 & & \\
\multicolumn{1}{c}{186} & & & & \\
\hline
\end{tabular}

When the scores of the participants from the life satisfaction scale were examined according to their status of playing sports, a significant difference was found between the scores. Accordingly, the life satisfaction scores of the participants who participate in sports were found to be significantly higher than the participants who do not participate in sports.

Pearson Product-Moment Correlation Analysis Results Conducted to Determine the Relationship between Participants'

\begin{tabular}{lcll}
\hline Variables & $\mathrm{n}$ & $\mathrm{r}$ & $\mathrm{p}$ \\
\hline Learned Helplessness & & & \\
Life Satisfaction & 186 & $-0.463^{* *}$ & .0o1 \\
\hline
\end{tabular}

\section{Discussion and Conclusion:}

A significant difference was found between the scores obtained from the learned helplessness scale according to the participants' status of playing sports. According to the results, the learned helplessness scores of the participants who do not do sports were found to be significantly higher than the participants who do sports. It can be said that the participants who do not do sports experience much more learned helplessness than the participants who do sports.

Arslan et al., (2011) did not detect a significant difference between the depression scores of women who do sports and women who do not. This research result is not in line with our research results. It can be said that obtaining a different result is due to both the difference between the study dates and the Covid-19 epidemic that captured the world at the time of our study.

Düzgün \& Hayalioğlu (2006), found on the learned helplessness level of male students was higher than the learned helplessness level of girls. In our society, it is usual for such a result to occur because boys are more involved in the social environment. It is a natural result that the learned helplessness of women who regularly go to sports centers or sports facilities for sports purposes is higher than that of women who do not do sports. This result is in parallel with similarstudies (Polat, 1986; Oluklu, 1997).

When the scores of the participants from the life satisfaction scale were examined according to their status of playing sports, a significant difference was found between the scores. Accordingly, the life satisfaction scores of the participants who do sports were found to be significantly higher than the participants who do not do sports. It can be said that participants who do sports have much more life satisfaction than participants who do not do sports.

When the results of the $\mathrm{t}$-Test related to life satisfaction of the women participating in the study according to their status of playing sports were examined, a significant difference was found between the scores. Accordingly, the life satisfaction scores of women who do sports were found to be significantly higher than women who do not do sports. According to this result, it can be said that women who do sports have more life satisfaction than women who do not do sports.

Doğaner (2017), applied a regular exercise program for a total of 45 participants residing in Ankara in a private sports center, 3 days a week, for a total of 8 weeks. As a result of the study, it was observed that the stress and insufficient self-efficacy perceptions of the people in the experimental group who participated in the regular exercise program decreased significantly compared to the people in the control group, and the happiness scores of the experimental group were significantly higher than the control group. It is also observed that leisure time satisfaction levels of people who participate in a regular exercise program increase compared to those in the control group and who do not participate in the regular exercise program. As a result, spending their leisure time by participating in a regular exercise program supports positive changes in their social and psychological mood. This is evidence that individuals can increase their happiness level by exercising. This study by Doğaner (2017) supports ourwork.

When the results of Pearson product-moment correlation analysis conducted to determine the relationship between the participants' learned helplessness and life satisfaction levels, a statistically negative, significant, and the high relationship was found between the scores at the level of $\mathrm{p}<.05$. According to this result, life satisfaction scores decrease as the learned helplessness scores increase, and life satisfaction scores increase as the learned helplessness scores decrease.

Polatçı \& Boyraz (2010) found that in teachers, role ambiguity was an important predictor for learned helplessness, and learned helplessness for job satisfaction. Yürür (2001) also found that learned helplessness affects teachers' emotional exhaustion levels (Yürür, 2011). Considering that emotional exhaustion affects life 
satisfaction, it can be said that learned helplessness is related to life satisfaction in this study. Şar et al., (2012) found that learned helplessness negatively affected teachers waiting to be appointed, but learned helplessness did not significantly predict life satisfaction.

Looking at these results, in summary, it can be said that the level of learned helplessness of an individual with a high level of life satisfaction will be low in the opposite direction to his/her life satisfaction. Finding a statistically significant negative and high relationship between learned helplessness and life satisfaction in our study shows that a solution should be found for the problem of learned helplessness to increase the life satisfaction of women. Regular exercise has a positive effect on individuals' learned helplessness and life satisfaction. In this respect, it is necessary to raise awareness in society in order to make the habit of doing sports a life philosophy.

\section{References:}

Abramson, L.Y., Metalsky, G.I. \& Alloy, L.B. (1989): Hopelessness Depression: A theory-based subtype of depression. Psychol. Review, (96):358-372.

Arslan, C., Güllü, M. \& Tutal, V. (2011): Spor Yapan Ve Yapmayan Ilkögretim Ögrentilerinin Depresyon Durumlarinin Bazi Degiskenlere Göre Incelenmesi. Nigde Üniversitesi Beden Egitimi Ve Spor Bilimleri Dergisi, 5 (2).

Bayat, B. (2002): Örgütlerde, 'güdülenme yetersizlikleri ve geri çekilme-kaçinma davranislarini"' açiklamakta kullanilabilecek bir model; "ögrenilmis çaresizlik. Gazi Üniversitesi Iktisadi ve Idari Bilimler Fakültesi Dergisi, 4(3):114 .

Bilecen, B. (2013): Ögrenilmis çaresizliklerimiz. Kisisel Gelisim Dergisi, 19:16-18.

Boysan, M. (2006): Çok örneklemli yapisal esitlik modelleri, (Yayimlanmamis yüksek lisans tezi), Yüzüncü Yil Üniversitesi Fen Bilimleri Enstitüsü, Van.

Budak, S. (2003): Psikoloji Sözlügü, Pub. by: Bilim ve Sanat Yayinlari, Ankara

Dagli, A. \& Baysal, N. (2016): Yasam doyumu ölçeginin Türkçe'ye uyarlanmasi: geçerlik ve güvenirlik çalismasi. Elektronik Sosyal Bilimler Dergisi, 15(59):1250-1262.
Diener, E., Emmons, R.A., Larsen, R.J. \& Griffin, S. (1985): The satisfaction with life scale. J. Pers. Asses., 49(1):71-75.

Doganer, S. (2017): Düzenli Egzersiz Programinin Bireylerin Stres, Mutluluk ve Serbest Zaman Doyum Düzeylerine Etkisi, Yayimlanmamis Doktora Tezi, Ankara Üniversitesi Saglik Bilimleri Enstitüsü, Ankara.

Düzgün, S. \& Hayalioglu, H. (2006): Ögrencilerde ögrenilmis çaresizlik düzeyinin bazi degiskenler açisindan incelenmesi. Kazim Karabekir Egitim Fakültesi Dergisi, 13:404-413.

Düzgün, S. \& Hayaloglu, H. (2006): “Ögrencilerde Ögrenilmis Çaresizlik Düzeyinin Bazi Degiskenler Açisindan Incelenmesi”. Kazim Karabekir Egitim Fakültesi Dergisi, i: 13.

Erkal, M. (1982): Sosyolojik Açidan Spor. Pub. by: Der Publication. Ankara. P-286.

Karasar, N. (2005): "Bilimsel arastirma yöntemi”. (15. Basim). Ankara: Nobel Yayin Dagitim.

Neugarten, B.L. \& Ark, (1961): The measurement of the life satisfaction. J. Gerontol., 16:134-143.

Oluklu, D. (1997): Lise ögrencilerinin ögrenilmis çaresizlik düzeylerinin bazi degiskenler açisindan incelenmesi. Unpublished master's thesis, Gazi University.

Özer, M. \& Karabulut, Ö. (2003): Yaslilarda Yasam Doyumu. Geriatri, 6(2):72-74.

Polat, S. (1986): "Ana-Baba Tutumlarinin Ortaokul Birinci Siniftaki Çocuklarin Ögrenilmis Çaresizlik Düzeyine Etkisi”. (Yayinlanmamis Yüksek Lisans Tezi). Ankara: Hacettepe Üniversitesi.

Seligman, M.E.P. (1975): Helplessness: On Depression, Development and Death. Pub. by: San Francisco: W.H. Freeman and Company.

Sar, A.H., Isiklar, A. \& Aydogan, I. (2012). Atama bekleyen ögretmen adaylarinin yasam doyumunu yordayici degiskenlerin incelenmesi. Mehmet Akif Ersoy Üniversitesi Egitim Fakültesi Dergisi, 23:257-271.

Yetim, Ü. (2001): Toplumdan Bireye Mutluluk Resimleri. Baglam Yayinlari. Istanbul. 